\title{
The effects of leadership styles on employee performance: a case of a selected commercial bank in Botswana
}

\author{
Ushe Makambe $^{1 *}$, Gaone Joy Motlatsi Moeng ${ }^{2}$ \\ Faculty of Business and Accounting, Botho University, Gaborone, Botswana ${ }^{1}$ \\ Department of Business Management, Botswana Open University, Gaborone, Botswana ${ }^{2}$ \\ makambe2006@gmail.com ${ }^{1 *}$, staff@ bou.ac.bw ${ }^{2}$
}

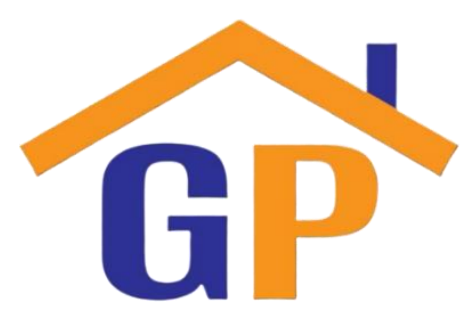

Article History

Received on 17 September 2020

Revised on 29 September 2020

Accepted on 8 October 2020

\begin{abstract}
Purpose: The leadership phenomenon is fundamental in providing employees with direction and emotional indulgence to derive maximum effort out of them. Therefore, it is vital that an organisation places uninhibited emphasis on the appropriate leadership style to enhance employee performance. Premised on the Collaborative Leadership Model, this paper sought to extricate the nexus between leadership style and employee performance at a selected bank in Botswana, focusing on the transactional, transformational, and participative leadership styles.
\end{abstract}

Research methodology: The study adopted a positivist research paradigm coupled with a survey research design, while a quantitative methodology was used to collect data through a selfadministered questionnaire. The study population comprised 433 employees from which a sample of 200 was randomly selected. Data was analysed through the Statistical Package for Social Sciences (SPSS), culminating in statistical techniques such as factor analysis, regression analysis and Analysis of Variance (ANOVA).

Results: The results of the study revealed that there was a significant utilisation of the participative, transformational, and transactional leadership styles at the selected commercial bank. However, while the use of the participative and transactional leadership styles had a positive and significant influence on employee performance, the transformational leadership style's effect was insignificant.

Limitation: The study only used quantitative data from employees for analysis and did not include bank leaders' opinions.

Contribution: The study contributed to the expansion of the body of knowledge on leadership style and employee performance in the banking sector in Botswana and elsewhere and helped to unmask the shortcomings of some styles while exposing the power of others in reaping positive reinforcements leading to enhancement of employee performance.

Keywords: Leadership, Leadership style, Employee performance, Participative leadership, Transformational leadership, Transactional leadership

How to cite: Makambe, U., \& Moeng, G. J. M. (2019). The effects of leadership styles on employee performance: a case of a selected commercial bank in Botswana. Annals of Management and Organization Research, 1(1), 39-50. 


\section{Introduction}

The importance of leadership in organisations cannot be overemphasised. The concept is critical in as far as it influences the present and future sustenance and productivity of an organisation. According to

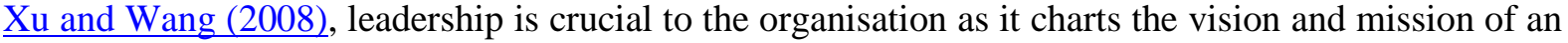
organisation as well as determining and establishing its objectives, strategies, procedures and means of effectively and efficiently achieving those objectives. Al Khajeh (2018) suggests that the leadership phenomenon is fundamental in providing employees with direction and psychological gratification to acquire the best out of them. It is vital that an organisation places unbridled focus on its leadership because it is the leaders' decisions that may decide the difference between the success and failure of an organisation. It is, therefore, generally believed that employees' success emanates from the actions of an effective leader which stimulate the desires of subordinates, translating to enhanced performance (Khan \& Adhan, 2014; Kužnin \& Walker, 2017).

Various authors allude to different leadership styles namely autocratic, transactional, transformational, participative, visionary, and culture-based styles (Mohammad et al., 2017; Sofi \& Devanadhen, 2015) with varying influences on employee performance hence organisational productivity. Therefore, leadership styles/practices targeting mobilisation of human resources are an important factor in determining organisational performance (Khan \& Adhan, 2014).

The banking industry is experiencing high employee turnover due to job dissatisfaction and high workload (Ojokuku et al., 2012). These authors suggest that to mitigate this, there is need for organisations to establish effective leadership through appropriate leadership styles. However, the adoption of different leadership styles at the selected bank has generated friction between managers and subordinates, and in some cases, loss of motivation. Some managers were opposed to the use of certain leadership styles because they believed they eroded their power while there was lack of receptivity of some leadership styles by some employees due to lack of understanding of the effects of these styles on employee performance. There are limited studies on the relationship between leadership style and employee performance in Botswana especially in banking sector. It is this observation that motivated this study to expand the body of knowledge on the nexus between leadership style and employee performance in the banking industry in Botswana focusing on the transactional, transformational, and participatory leadership styles.

\section{Literature review}

This section reviews the extant literature on the effects of the transactional, transformational, and participative leadership styles on employee performance.

\subsection{Transactional leadership}

The transactional leadership style is a sanction and reward leadership model where the leader converses the need and the resultant compensation for fulfilling that need (Kužnin \& Walker, 2017) as well as the corresponding chastisement for failure. For positive performance, the subordinate is rewarded in a material or non-material way while negative performance is punishable (Kužnin \& Walker, 2017) through several overt and covert practices.

Groves (2014) argues that a leader is said to be a transactional one when he/she, most of the time, offers something to reciprocate positive behaviour. This might include rewards such as promotion, salary increase, performance reviews, and expanded job responsibilities. One unique attribute of transactional leadership is the reward expectation hence the style is the exchange of targets and rewards between the management and the lower level employees (Kužnin \& Walker, 2017).

Groves (2014) further notes that transactional leaders inspire people to take an interest in themselves. As a result, such leaders can minimize workplace anxiety by concentrating on specific business priorities such as high quality, productive customer support, cost reduction and output increase. Longe (2014) argues that the transactional leadership approach could be effective in banks. The short-term 
existence of transactions involving the temporary exchange of gratifications can, however, generate a sense of dissatisfaction between bank leaders and their employees.

Research has established that the effects of transactional leadership on organisational performance may be both positive and negative. For example, Longe (2014) established that the transactional leadership style resulted in a positive effect on organisational performance in some banks in Nigeria. The author further established that the style also assisted in creating, optimising, and sustaining employee capabilities as these employees frequently succeeded in achieving tangible and intangible rewards. The same author further observes that transactional leadership also fosters a forceful vision that improves the overall performance of the organisation.

In contrast to the above finding, Sofi and Devanadhen (2015) argue that transactional leadership does not directly affect an organisation's performance as it discourages creativity and innovation among staff leading to low performance. The impact of transactional leadership depends on the organisational context and how it is applied.

\subsection{Transformational leadership}

According to Jyoti and Bhau (2015), transformational leadership is a process that motivates followers by appealing to higher ideas and entrenched internal moral values which the leader uses to motivate followers to act in a manner that sustains organisational rather than self-interest. Puni et al. (2018) aver that a transformational leader identifies subordinates' needs which he/she seeks to meet with full involvement of followers. However, Jyoti and Bhau (2015) suggest that good leaders adopt a marriage of transactional and transformational leadership so that they complement each other.

Chan and Mak (2014) assert that transformational leadership hinges on the personality and capability of the leader to effect positive change by articulating a motivating vision and energising goals which enhance employee performance. Zwingmann et al. (2014) posit that the central idea underpinning the transformational leadership theory is the belief that transformational leaders change the values, beliefs, norms, and attitudes of followers thereby influencing them to perform above the threshold outcome specified by the organisation. Sun et al. (2014) reinforce this view suggesting that transformational leadership is inspirational, and leaders can effectively change followers' beliefs, thoughts, and behavioural tendencies for the benefit of the organisation. The authors believe that transformational leaders achieve that change by assisting followers to appreciate the criticality of the collective and how organisational outcomes positively influence employees' performance.

Al Khajeh (2018) reinforces the above view arguing that transformational managers focus on the development of a generic value system for the organisation's employees thus upgrading employee morality, skills, and inspiration. The author further postulates that transformational leadership becomes the passageway between the leaders and their subordinates in the development of an understanding that is linked to the inspirational level, the values, and the deep-seated interests of the workers thus enhancing employee and team performance.

Through evaluating how leadership's effect on the wellbeing of individual workers (the mutual opinions of workers about leadership) is and whether transformative and transactional leaders have healthier employees, Zwingmann et al . (2014) found that providing a good atmosphere of transformative leadership is correlated with better perception. In general, a common vision and specific priorities, responsibilities and awards in the workplace are important to promote the wellbeing of employees.

Wang et al. (2011) and Sofi and Devanadhen (2015) believe that transformational leadership significantly affects organisational performance through its effect on employee motivation, hence morale, which in turn enhances employee effort. Furthermore, a significant positive relationship between transformational leadership and performance of teams at organisational level has been recorded by several researchers (Xu \& Wang, 2008; Wang, et al., 2011; Sofi \& Devanadhen, 2015). Xu and Wang (2008) further note that this relationship is a result of enhanced employee performance emanating 
from improved skills, capabilities, know-how and inspiration of employees which are all directed towards positive behaviour that promotes organisational interests. The study carried out by the abovementioned researchers revealed that transformational leadership improves the general progression of the followers which enhances their work performance and output. It is the essence of this study to confirm if this was indeed the case at the selected bank.

\subsection{Participative leadership}

Puni et al. (2018) postulate that participative leadership is the procedure of making combined decisions or sharing responsibilities in decision-making between the authorities and employees and that it involves consulting with subordinates and evaluating their opinions and suggestions before the manager makes any decision. It is associated with consensus, consultation, delegation, and involvement (Sofi \& Devanadhen, 2015). Scholars affirm that this leadership style has many benefits. Bell and Mjoli (2014), for example, argue that it is likely to enhance the appropriateness of decisions while contributing to the quality of employees' work lives.

Puni et al. (2018) assert that the participative leader exhibits consultative behaviours such as imploring subordinates for ideas prior to making an ultimate decision although the leader retains the final authority. Furthermore, the participative leader shares duties with subordinates by including them in the decision-making process such as the preparation, decision-making, and implementation phases (Northouse, 2014; Quick \& Nelson, 2013). Research suggests that employees who are involved in decision-making become more motivated, self-directed and exhibit an inspired team spirit that enhances organisational performance (Hersey \& Blanchard, 2010).

The main emphasis of participative leadership is on consultation with followers before making key organisational decisions. Therefore, it is argued that bringing employees on board when making decisions about the company's future helps strengthen the existing relationship between them and the leadership. This leads to the leaders gaining respect from their employees and instils a sense of responsibility in the workforce (Jones, 2013).

The benefits associated with participative leadership include increased trust in the leaders by their subordinates (Quick \& Nelson, 2013). Leaders who make decisions while keeping employees in the dark may lose the trust of their subordinates (Jones, 2013). Involving employees in the organisation's decision-making process enables leaders to bring transparency to the workplace which enhances employee morale and organisational performance (Quick \& Nelson, 2013). It is suggested that this leadership style might be suitable for the banking industry where employee motivation is vital for employee performance hence bank performance.

\subsection{Conceptual model}

This study is premised on the Collaborative Leadership Model (CLM) shown in Figure 1 below.

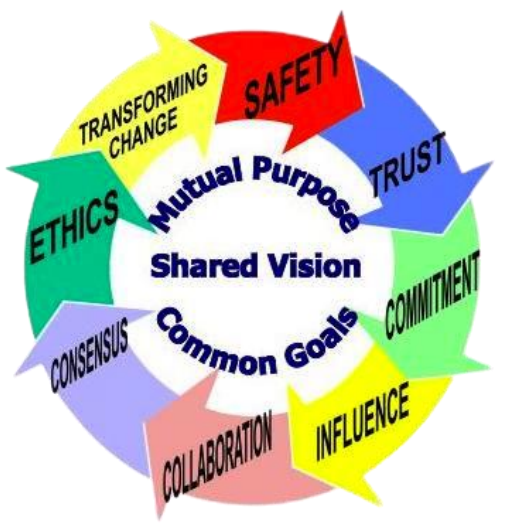

Figure 1: Collaborative Leadership Model (Adapted from $\underline{\text { Sawyer, 2007, p. 88) }}$ 
Figure 1 above shows leadership as an influence relationship which fosters safety, trust, and commitment, among leaders and their subordinates who are partners leading to substantive or transforming change that reflects their mutual purpose, shared vision, and common goals. The need for collaboration is believed to be a result of complexity in today's organisations. The CLM is appropriately suited for the 21st century because it is premised on trust which nurtures the establishment of an interlocking network of relationships among people who are labouring to generate a movement leading to organisational transformation. Elements of the CLM that capture the dictates of particularly the transformational and participative leadership styles include the shared vision and common goals, fostering trust and commitment to the organisation, partnership between leaders and subordinates, mutual purpose, bringing about organisational transformation, and formation of interlocking network of relationships.

\section{Research questions and hypotheses}

Based on the literature that was reviewed in Section 2 above, the purpose of this study was to explicate the effects of identified leadership styles on employee performance at a selected commercial bank in Botswana. The study therefore sought to answer the following research questions:

- What are the effects of transactional leadership on employee performance at the selected commercial bank?

- What are the effects of transformational leadership on employee performance?

- What are the effects of participative leadership on employee performance?

Grounded on the above research questions, the following hypotheses were tested in this study:

H1: There is a significant and positive relationship between the transactional leadership style and employee performance at the selected commercial bank.

$\mathrm{H} 2$ : There is a significant and positive relationship between the transformational leadership style and employee performance at the selected bank.

H3: There is a significant and positive relationship between the participative leadership style and employee performance at the selected bank.

It is crucial in a study to identify correct research questions and hypotheses as these assist in shaping and explicitly focusing the purpose of the study thus illuminating the relationships among the variables that the study is investigating as well as the accurateness of the predictions that the researcher insinuates about those relationships (Creswell, 2014; Creswell \& Plano-Clark, 2011).

\section{Research methodology}

For this study, a positivist paradigm was adopted. Positivism involves placing an emphasis on a quantifying phenomenon through statistical analysis and generalising the findings (Cohen, et al., 2011). The research design which suits positivism, and was adopted for this study, is a survey. A quantitative research methodology was used to collect numerical data for analysis. This form of methodology is usually associated with hypothesis testing hence some hypotheses were tested as indicated in Section 2.

The study population comprised 433 employees from which a sample of 200 was adopted as representative of the population based on the suggestions of some statistical experts (Hair, et al, 2010). The simple random sampling technique was used to select the respondents which afforded all elements of the population an equal opportunity to participate in the study thus eliminating sampling bias (Alvi, 2016; Neuman, 2014).

Data for the study was collected using a questionnaire with closed-ended questions after the attainment of ethical clearance. The questionnaire adopted the five-point Likert scale. Of the 200 questionnaires that were distributed, 148 were returned culminating in a $74 \%$ response rate which is good as suggested by some research experts who assert that a response rate of approximately $60 \%$ should be the goal of researchers (Neuman, 2014). 
Data was processed and analysed using the Statistical Package for Social Sciences (SPSS) version 2.0 which is popular owing to its capability to accomplish extremely intricate data manipulation and analysis with simple and straightforward instructions from a menu. Both descriptive and inferential statistics were applied in data analysis. Descriptive statistics involved the use of frequency tables and percentages which was meant to provide simple summaries about the sample and the measures that formed the basis for the study. Inferential statistics were applied in the form of factor analysis, regression analysis, and one-way Analysis of Variance (ANOVA) which were intended to explicate the relationships between the various leadership styles and employee performance at the selected commercial bank. The one-way ANOVA test was used to determine whether there were any statistically significant differences between the means of the three independent (unrelated) groups namely transactional, transformational and participative leadership styles and employee performance (the dependent variable).

Reliability and validity were ensured in this study. The reliability of the measuring scales was tested using the Cronbach alpha coefficient to calculate internal consistency of the instrument which is the most objective measure of reliability in cases where participants respond to questions anchored on a Likert scale (Cohen, et al., 2011). These authors suggest that a value of at least 0.6 is acceptable and the closer the Cronbach's alpha coefficient is to 1.00 , the higher the instrument's internal consistency reliability.

The validity of the questionnaire was established through testing and re-testing the research instrument to ensure that it solicited the responses it was meant to obtain and also sharing it with statistical experts for their input (Cohen, et al., 2011; Kumar, 2011).

\section{Results and discussion}

Before a full-scale data analysis was conducted, a reliability test was performed to establish if the scale items possessed internal consistency. The results are shown in Table 1 below.

Table 1: Reliability test based on Cronbach's Alpha

\begin{tabular}{|l|l|l|}
\hline Variables & Number of items & Cronbach's Alpha \\
\hline Transactional leadership style & 8 & 0.829 \\
\hline Transformational leadership style & 6 & 0.877 \\
\hline Participative leadership style & 8 & 0.886 \\
\hline
\end{tabular}

Table 1 above displays the Cronbach's Alpha test results for reliability of the measurement instrument. The responses for all the variables were good in terms of internal consistency as they were well above 0.6 and closer to 1 .

\subsection{The use of transactional leadership style at the selected commercial bank and effect on employee performance}

The study sought to establish whether the managers at the selected commercial bank were using the transactional leadership style and what its effects on the performance of the bank's employees were. The results are shown in Table 2 below.

Table 2: Extent of the use of transactional leadership style and effect on employee performance

\begin{tabular}{|l|c|c|c|c|c|}
\hline \multicolumn{1}{|c|}{ Constructs } & SD & D & NS & A & SA \\
\hline $\begin{array}{l}\text { Managers in my organisation use reward and punishment as } \\
\text { strategies for increasing productivity. }\end{array}$ & 1.0 & 9.2 & 9.2 & 79.6 & 1.0 \\
\hline $\begin{array}{l}\text { Managers in my organisation reprimand subordinates when } \\
\text { they fail to complete their work target. }\end{array}$ & 0 & 0.0 & 20.4 & 79.6 & 0.0 \\
\hline $\begin{array}{l}\text { My supervisor clarifies expectations and closely monitors } \\
\text { subordinates to enhance performance and productivity. }\end{array}$ & 0.0 & 0.0 & 34.7 & 39.8 & 25.5 \\
\hline $\begin{array}{l}\text { Managers in my organisation provide rewards in exchange for } \\
\text { good performance. }\end{array}$ & 1.0 & 4.1 & 19.4 & 52.0 & 23.5 \\
\hline
\end{tabular}




\begin{tabular}{|l|c|c|c|c|c|}
\hline $\begin{array}{l}\text { Managers in my organisation provide rewards when } \\
\text { subordinates achieved organisational goals. }\end{array}$ & 1.0 & 2.0 & 27.6 & 45.9 & 23.5 \\
\hline $\begin{array}{l}\text { In my organisation, many employees have left because they are } \\
\text { not happy with the style of leadership. }\end{array}$ & 0.0 & 2.0 & 28.6 & 37.8 & 31.6 \\
\hline $\begin{array}{l}\text { Managers in my organisation use reward and punishment as } \\
\text { strategies for increasing productivity. }\end{array}$ & 0.0 & 1.0 & 18.4 & 69.4 & 11.2 \\
\hline $\begin{array}{l}\text { Managers in my organisation tell subordinates what to do if they } \\
\text { want to be rewarded for their work. }\end{array}$ & 0 & 1.0 & 14.3 & 48.0 & 36.7 \\
\hline
\end{tabular}

Key: SD (strongly disagree), D (disagree), NS (Not sure), A (Agree), SA (Strongly agree)

The results in Table 2 above indicate that the managers of the selected bank utilised the transactional leadership style to a significant extent. For example, $84.7 \%$ of the respondents indicated that managers instructed subordinates on what to do if the subordinates wanted to be rewarded for their work, while $80.6 \%$ indicated that managers used reward and punishment as strategies for increasing productivity. Furthermore, $79.6 \%$ of the respondents believed that managers at the bank reprimanded subordinates when they failed to meet their work targets, while $75.5 \%$ agreed that the managers of the bank provided rewards in exchange for good performance. The findings in Table 2 also indicate that $69.4 \%$ of the respondents opined that managers at the bank offered rewards to subordinates who achieved organisational goals.

The findings shown in Table 2 exhibit characteristics of transactional leadership and hence affirm that managers at the bank made significant use of transactional leadership as one of the dominant leadership styles. For instance, the use of reward and punishment as strategies for increasing productivity and telling subordinates what to do if they wanted to be rewarded for their work are popular traits of the transactional leadership style. In addition to the above findings, results from the regression analysis showed that the use of transactional leadership positively influenced employee performance at the bank (see Table 8). These findings confirm the views of Longe (2014) who established that the transactional leadership style had a positive impact on the organisational performance of the cement industry in Nigeria. The implication of this finding is that transactional leadership could have both positive and negative effects on an organisation.

\section{2: The extent of the use of the transformational leadership style at the selected bank and effects on employee performance}

The study sought to determine the extent to which the managers at the selected bank were using the transformational leadership style and whether its effects on employee performance was negative or positive. The results are indicated in Table 3 below.

Table 3: The extent of usage of the transformational leadership style and effects on employee performance

\begin{tabular}{|l|c|c|c|c|c|}
\hline \multicolumn{1}{|c|}{ Constructs } & SD & D & NS & A & SA \\
\hline $\begin{array}{l}\text { Managers in my organisation help subordinates to develop } \\
\text { themselves in their job. }\end{array}$ & 1.0 & 10.2 & 7.1 & 69.4 & 12.2 \\
\hline $\begin{array}{l}\text { Managers in my organisation instill trust, faith, and confidence } \\
\text { among subordinates. }\end{array}$ & 0.0 & 2.0 & 11.2 & 59.2 & 27.6 \\
\hline $\begin{array}{l}\text { Leaders in my organisation encourage subordinates to think about } \\
\text { old problems in new ways. }\end{array}$ & 1.0 & 1.0 & 17.3 & 57.1 & 23.5 \\
\hline $\begin{array}{l}\text { Leaders in my organisation provide subordinates with new ways of } \\
\text { looking at puzzling things. }\end{array}$ & 0.0 & 10.2 & 12.2 & 53.1 & 24.5 \\
\hline $\begin{array}{l}\text { Leaders in my organisation assist others to rethink ideas that they } \\
\text { had never questioned before. }\end{array}$ & 1.0 & 3.1 & 35.7 & 36.7 & 23.5 \\
\hline $\begin{array}{l}\text { Leaders in my organisation devote time to understand employees' } \\
\text { needs. }\end{array}$ & 0.0 & 8.2 & 11.2 & 77.6 & 3.1 \\
\hline
\end{tabular}


The results in Table 3 above show a significant adoption of the transformational leadership style by the managers of the selected commercial bank. To illustrate, $81.6 \%$ of the respondents believed that the managers at the bank helped subordinates to develop themselves in their job, while $86.8 \%$ suggested that the managers at the bank instilled trust, faith, and confidence in the subordinates. A good $80.6 \%$ of the respondents indicated that the leaders at the bank encouraged subordinates to think about old problems in new ways, while $77.6 \%$ believed that the leaders at the bank provided subordinates with new ways of looking at puzzling phenomena. A good $80.7 \%$ of the respondents indicated that the leaders at the bank devoted time to understand employees' needs.

The above findings reveal some interesting results. While the results in Table 3 show that the managers of the selected bank used transformational leadership to a large extent, the results from the regression analysis indicated that this leadership style did not have a significant impact on employee performance (see Table 8). The implication of this finding is that transformational leadership did not provide much benefit to the management of the selected bank in terms of enhancing employee performance. This finding contradicts the views of Wang et al. (2011) and Sofi and Devanadhen (2015) who believe that transformational leadership has a significant and positive impact on the performance of an organisation.

\subsection{The extent of the use of the participative leadership style at the selected commercial bank and effects on employee performance}

The study also sought to establish the extent to which the managers at the selected bank used the participative leadership style and its influence on employee performance. The findings are depicted in Table 4 below.

Table 4: The extent of the use of the participative leadership style and effect on employee performance

\begin{tabular}{|l|c|c|c|c|c|}
\hline \multicolumn{1}{|c|}{ Constructs } & SD & D & NS & A & SA \\
\hline $\begin{array}{l}\text { Leaders in my organisation always consult with subordinates before } \\
\text { making major decisions. }\end{array}$ & 7.1 & 1.0 & 31.6 & 35.7 & 24.5 \\
\hline My supervisor delegates authority to subordinates. & 0.0 & 7.1 & 11.2 & 64.3 & 17.3 \\
\hline My supervisor asks for employees' suggestions on most issues. & 0.0 & 7.1 & 20.4 & 45.9 & 26.5 \\
\hline My supervisor involves employees in making major decisions. & 0.0 & 7.1 & 50.0 & 28.6 & 14.3 \\
\hline My supervisor listens to employees' opinions on most issues & 2.0 & 7.1 & 2.0 & 63.3 & 25.5 \\
\hline $\begin{array}{l}\text { My supervisor allows employees to make critical decisions in their areas } \\
\text { of jurisdiction (empowerment) }\end{array}$ & 0.0 & 7.1 & 10.2 & 44.9 & 37.8 \\
\hline My supervisor is good at sharing information. & 0.0 & 1.0 & 17.3 & 32.7 & 49.0 \\
\hline The leadership style in my organisation enhances employee performance. & 0.0 & 0.0 & 21.4 & 51.0 & 27.6 \\
\hline
\end{tabular}

The results in Table 4 above indicate that the participative leadership style was being used by managers at the selected bank to a significant extent as buttressed by the following statistics:

- Managers listening to employees' opinions on all issues $-88.8 \%$.

- Empowerment of employees - $82.7 \%$.

- Sharing information with, and among, employees $-81.7 \%$.

- Delegating authority to subordinates $-81.6 \%$.

- Asking employees' suggestions on all issues $72.4 \%$, and

- Consulting with subordinates before making major decisions $-60.2 \%$.

The above findings are strong characteristics of participative leadership and are evidence that the managers at the bank were using the participative leadership style to a large extent at the time this study was conducted. These findings are corroborated by the regression analysis results that are shown in Table 5 which affirm that the use of the participative leadership style at the selected commercial bank positively impacted on the employee and bank performance. Therefore, the use of this leadership style is encouraged, especially the attribute that urges leaders to motivate subordinates to think about old problems in new ways as it was found to be highly correlated with participative leadership as shown in Table 4 where the supervisor asked for employees' suggestions on most issues. This finding is supported 
by the studies of Luthan (2011), Jones (2013), Quick and Nelson (2013) and others who discovered a significant positive correlation between the participative leadership style and employee performance.

The study results are also supported by previous other researchers on leadership style and employee performance namely Bell and Mjoli (2014), Northouse (2014) and Puni et al. (2018) who concur that employees more readily accept and appreciate involvement in decision making and all facets of organisational life such as delegation of authority and responsibility, appreciation and taking on board employee opinions and suggestions and empowerment and the sharing of information across the organisation. The respondents confirmed that within the selected commercial bank, employees were empowered to make decisions and shared information across departments and bank branches (See Table 4).

The findings in Table 2, Table 3 and Table 4 confirm a significant adoption of the transactional, transformational, and the participative leadership styles at the commercial bank covered in this study which is in tandem with the essence of the CLM (Figure 1) whose gist is that leadership is an influence relationship which fosters safety, trust, and commitment between leaders and their subordinates who are partners in an organisation leading to substantive or transforming change that reflects their mutual purpose, shared vision and common goals. Elements of the CLM that were found to be essential in the transformational and participative leadership styles used at the selected bank include shared vision and common goals, fostering trust and commitment to the organisation, partnership between leaders and subordinates, mutual purpose, bringing about organisational transformation, and formation of interlocking network of relationships. This provides amble evidence of the relationship between the CLM (Figure 1) and the leadership styles adopted by the managers of the commercial bank covered in this study.

\subsection{Inferential statistics}

Factor analysis, one-way ANOVA, and multiple linear regression analysis were also conducted to test the correlation and relationships between the dependent variable (employee performance) and independent variables (leadership styles) as shown in Table 5 and Table 6 below.

Table 5: Factor analysis (Component matrix)

\begin{tabular}{|l|c|c|c|c|c|c|c|}
\hline \multicolumn{2}{|l}{} & \multicolumn{2}{c|}{$\begin{array}{c}\text { Transactional } \\
\text { leadership style }\end{array}$} & \multicolumn{2}{c|}{$\begin{array}{c}\text { Transformational } \\
\text { leadership style }\end{array}$} & $\begin{array}{c}\text { Participative leadership } \\
\text { style }\end{array}$ \\
\hline EDS6 & .910 & TRLS5 & .822 & TFLS1 & .866 & PATLS3 & .887 \\
\hline LDS3 & .869 & TRLS6 & .800 & TFLS8 & .852 & PATLS6 & .848 \\
\hline LDS7 & .868 & TRLS1 & .776 & TFLS5 & .829 & PATLS7 & .816 \\
\hline LDS6 & .855 & TRLS4 & .750 & TFLS3 & .782 & PATLS2 & .785 \\
\hline LDS9 & .852 & TRLS7 & .711 & TFLS4 & .668 & PATLS4 & .755 \\
\hline LDS2 & .849 & TRLS3 & .582 & TFLS7 & .664 & PATLS5 & .698 \\
\hline LDS5 & .813 & TRLS2 & .468 & TFLS2 & .608 & PATLS1 & .668 \\
\hline LDS4 & .731 & & & TFLS6 & .582 & PATLS8 & .529 \\
\hline LDS1 & .574 & & & & & & \\
\hline
\end{tabular}

The results in Table 5 above indicate that employee performance was highly correlated with the construct LDS8 (0.910) followed by LDS3 (0.869). Also, transactional leadership style was highly correlated with TRLS5 (0.822). Transformational leadership style was highly correlated with the construct TFLS1 (0.866) while participative leadership was highly correlated with the construct PATLS3 (0.887). 
Table 6: Model summary

\begin{tabular}{lc|c|c|c} 
Model & $\mathrm{R}$ & $\mathrm{R}$ Square & $\begin{array}{c}\text { Adjusted } \mathrm{R} \\
\text { Square }\end{array}$ & Std. Error of the Estimate \\
\hline 1 & $.964^{\mathrm{a}}$ & .930 & .928 & .26872259 \\
\hline
\end{tabular}

a. Predictors: (Constant), Participative leadership style, Transactional leadership style,

Transformational leadership style

The results in Table 6 above show that the independent variable (leadership styles) explains $93 \%$ of the variability found in the dependent variable (employee performance). Furthermore, it shows that about $93 \%$ of the variation in employee performance is explained by the model (R-squared $=0.930$ and adjusted R-squared=0.928).

\section{Analysis of variance}

A one-way ANOVA was conducted to test the nexus between the leadership styles practised at the selected bank and employee performance. The results are displayed in Table 7 below.

Table 7: One-way ANOVA

\begin{tabular}{llr|r|r|r|r} 
& \multicolumn{5}{c}{ ANOVA $^{\text {a }}$} \\
Model & & Sum of Squares & df & Mean Square & F & Sig. \\
\hline 1 & Regression & 89.284 & 3 & 29.761 & 412.141 & $.000^{\text {b }}$ \\
\cline { 2 - 7 } & Residual & 6.716 & 93 & .072 & & \\
\cline { 2 - 7 } & Total & 96.000 & 96 & & & \\
\hline
\end{tabular}

a. Dependent Variable: Employee performance

b. Predictors: (Constant), Participative leadership style, Transactional leadership style, Transformational leadership style

The results of the one-way ANOVA test in Table 7 above indicate that the independent variable significantly predicts the dependent variable because Sig. 0.000 is less than 0.05 . This means that participative leadership style was used most at the selected bank compared to the other leadership styles.

\section{Multiple linear regression analysis}

To test the value of each leadership style, a multiple linear regression analysis was conducted. The results are shown in Table 8 below.

Table 8: Multiple linear regression analysis

\begin{tabular}{|c|c|c|c|c|c|c|}
\hline \multirow[b]{3}{*}{ Model } & & \multicolumn{2}{|c|}{ Coefficients $^{a}$} & \multirow[b]{2}{*}{$\begin{array}{l}\text { Standardized } \\
\text { coefficients }\end{array}$} & \multirow[b]{3}{*}{$\mathrm{t}$} & \multirow[b]{3}{*}{ Sig. } \\
\hline & & \multicolumn{2}{|c|}{$\begin{array}{l}\text { Unstandardized } \\
\text { coefficients }\end{array}$} & & & \\
\hline & & B & Std. Error & Beta & & \\
\hline 1 & (Constant) & -.011 & .027 & & & 9.699 \\
\hline & Transactional leadership style & .651 & .050 & .627 & 13.0 & 1.000 \\
\hline & $\begin{array}{l}\text { Transformational leadership } \\
\text { style }\end{array}$ & .019 & .060 & .019 & & 0.750 \\
\hline & Participative leadership style & .454 & .041 & .450 & 11.2 & 2.000 \\
\hline
\end{tabular}

Table 8 above displays the regression analysis results for leadership style and employee performance at the selected bank. The results demonstrate that the transactional and participative leadership styles were positively associated with employee performance and were statistically significant at the $5 \%$ level with p-value $<0.000$ and 0.000 , respectively. On the other hand, transformational leadership was found to be negatively associated with employee performance with p-value $>0.750$. This shows that the enhancement of the transformational leadership style may not have had any significant effect on employee performance at the bank. 


\section{Conclusion}

As already indicated, this study was meant to establish the leadership styles that were prominently used by a selected commercial bank in Botswana and their effects on employee performance. The conclusions of the study are premised on the extant literature on the effects of leadership styles on employee performance and the findings of the empirical investigation on the extent of the adoption and utilisation of transactional leadership style, transformational leadership style and participative leadership style by the managers of the selected bank. The results of the study revealed that the transactional, transformational and participative leadership styles were extensively used by the managers of the selected bank and that the transactional and participative leadership styles should be promoted since their positive influence on sustainable employee performance is well documented while the use of the transformational leadership style needs to be revamped so that its utilisation would have positive effects on employee performance in the long term as supported by the extant literature.

Although conclusions have been drawn, there are issues that need further investigation. Since the study used quantitative data from employees for analysis, it is suggested that the triangulation strategy from mixed methods be applied in future research in order to have an in-depth inquiry on the effects of leadership styles on employee performance. Also, it is necessary to include the opinions of bank leaders in future research to explore effective leadership practices from their perspective.

This study has further implications for further research. The study covered only Gaborone head office. It cannot be conclusive especially considering that the study has not been conducted in other branches in Gaborone and other cities. Future researchers may want to focus on all the branches of the commercial bank in Botswana to effectively generalise the findings to the selected bank and the entire banking sector in the country. Therefore, future researchers may want to expand the sample size and extend the study coverage across all commercial banks in Botswana. In the same way, global business practices will profit tremendously if researchers concentrate on exploring types of leadership of managers across organisations in different countries especially given the impact of the 4th Industrial revolution on business.

\section{References}

Al Khajeh, E. H. (2018). Impact of leadership styles on organizational performance. Journal of Human Resources Management Research, 2018(2018), 1-10.

Alvi, M. H. (2016). A manual for selecting sampling techniques in research. Munich Personal RePEc Archive, MPRA Paper No. 70218.

Bell, C., \& Mjoli, T. (2014). The effects of participative leadership on organisational commitment: Comparing its effects among two gender groups among bank clerks. African Journal of Business Management, 8(12), 451-459.

Chan, S. C., \& Mak, W. M. (2014). Transformational leadership, pride in being a follower of the leader and organizational commitment. Leadership \& Organization Development Journal.

Cohen, L., Manion, L., \& Morrison, K. (2011). Research methods in education. London: Routledge.

Creswell, J. W., \& Plano-Clark, V. L. (2011). Designing and conducting mixed methods research. Sage: Thousand Oaks.

Creswell, J.W. (2014). Research design: Qualitative and quantitative and mixed methods approaches. Los Angeles: Sage.

Groves, K. S. (2014). Examining leader-follower congruence of social responsibility values in transformational leadership. Journal of Leadership \& Organizational Studies, 21, 227-243.

Hair, J.F. Jr., Black, W.C., Babin, B.J., \& Anderson, R.E. (2010). Multivariate data analysis, 7th ed. Upper Saddle River, NJ: Prentice Hall.

Hersey, P., \& Blanchard, K. (2010). Management of organizational behaviour. New Jersey: Prentice Hall.

Jones, G. R. (2013). Contemporary Management. Indiana: McGraw-Hill Press.

Jyoti, J., \& Bhau, S. (2015). Impact of transformational leadership on job performance: Mediating role of leader-member exchange and relational identification. SAGE Open, 1-13. 
Khan, A., \& Adnan, N. (2014). Impact of leadership styles on organizational performance. International Journal of Management Sciences, 2(11), 501-515.

Kumar, R. (2011). Research methodology. New Delhi: Pearson Education.

Kužnin, M., \& Walker, J.K. (2017). Contemporary leadership challenges in hospitality organizations in times of uncertainty and change. DIEM: Dubrovnik International Economic Meeting, 3(1), 455468.

Longe, O. J. (2014). Leadership style paradigm shift and organisational performance: A case of the Nigerian Cement Industry. African Research Review, 8(4), 68-83.

Luthan, F. (2011). Organizational behavior: An evidence-based approach. Boston: McGraw-Hill Press.

Mohammad, I., Chowdhury, S. R., \& Sanju, N. L. (2017). Leadership styles followed in the banking industry of Bangladesh: A case study of some selected banks and financial institutions. American J. of Theoretical and Applied Business, 3(3), 36-49.

Neuman, W. L. (2014). Social research methods: Qualitative and quantitative approaches, 7th ed. London: Pearson.

Northouse, P. (2014). Leadership Theory and Practice. Thousand Oaks: Sage Publications Inc.

Ojokuku, R., Odetayo, T., \& Sajuyigbe, A. (2012). Impact of leadership style on organisational performance: A case study of Nigerian banks. American Journal of Business and Management, 1(4), 202-207.

Puni, A., Mohammed, I., \& Asamoah, E. (2018). Transformational leadership and job satisfaction: The moderating effect of contingent reward. Leadership \& Organisation Development Journal, 39(4), $522-537$.

Quick, J. C., \& Nelson, D. L. (2013). Principles of organizational behaviour: Realities \& Challenges. London: Cengage Press.

Sawyer, K. (2007). Group genius: The creative power of collaboration. New York: Basic Books.

Sofi, M.A., \& Devanadhen, D.K. (2015). Impact of leadership styles on organizational performance: An empirical assessment of the banking sector in Jammu and Kashmir. IOSR Journal of Business and Management, 17(8), 31-45.

Sun, W., Xu, A., \& Shang, Y. (2014). Transformational leadership, team climate, and team performance within the NPD team: Evidence from China. Asia Pacific Journal of Management, 31, 127-147.

Wang, F. J., Chich-Jen, S., \& Mei-Ling, T. (2011). Effect of leadership style on organisational performance as viewed from human resource management strategy. African Journal of Business Management, 4(18), 3924-3936.

$\mathrm{Xu}, \mathrm{G}$. Y. \& Wang, Z. S. (2008). The impact of transformational leadership style on organizational performance: The intermediary effects of leader-member exchange. Long Beach, CA, USA, IEEE Xplore, pp. 1090-1097

Zwingmann, I., Wegge, J., Wolf, S., Rudolf, M., Schmidt, M., \& Richter, P. (2014). Is transformational leadership healthy for employees? A multilevel analysis in 16 nations. German Journal of Research in Human Resource Management, 28(1-2), 24-51. 